\title{
BioéthiqueOnline
}

\section{How Gene Patents May Inhibit Scientific Research}

\section{Lisa Campo-Engelstein et Tiffany Chan}

Volume 4, 2015

Reçu : 25 Nov 2014; publié : 10 Feb 2015; éditrices : Cécile Bensimon \& Aliya Affdal

URI : https://id.erudit.org/iderudit/1035490ar

DOI : https://doi.org/10.7202/1035490ar

Aller au sommaire du numéro

Éditeur(s)

BioéthiqueOnline

ISSN

1923-2799 (numérique)

Découvrir la revue

Citer cet article

Campo-Engelstein, L. \& Chan, T. (2015). How Gene Patents May Inhibit Scientific Research. BioéthiqueOnline, 4. https://doi.org/10.7202/1035490ar

\section{Résumé de l'article}

Dans cet article, nous mettons en évidence trois façons dont les brevets sur les gènes pourraient nuire à la recherche scientifique. Premièrement, les lois relatives aux brevets sur les gènes risquent d'exacerber la culture du secret omniprésente en science. Deuxièmement, sans un accès à toutes les étiologies génétiques, les brevets sur les gènes peuvent limiter la capacité des chercheurs à étudier les maladies poly ou multigénétiques. Troisièmement, les brevets sur les gènes pourraient aboutir à un « maquis de brevets ».
Droits d'auteur (c) L Campo-Engelstein et T Chan, 2015

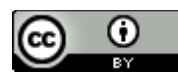

Ce document est protégé par la loi sur le droit d'auteur. L'utilisation des services d'Érudit (y compris la reproduction) est assujettie à sa politique d'utilisation que vous pouvez consulter en ligne.

https://apropos.erudit.org/fr/usagers/politique-dutilisation/ 


\title{
How Gene Patents May Inhibit Scientific Research
}

\author{
COMMENTAIRE / COMMENTARY \\ Lisa Campo-Engelstein, $\mathrm{PhD}^{1}$, Tiffany Chan, $\mathrm{MD}^{2}$ \\ Reçu/Received: 25 Nov 2014 \\ Publié/Published: 10 Feb 2015 \\ Éditrices/Éditors: Cécile Bensimon \& Aliya Affdal
}

2015 L Campo-Engelstein, T Chan, Creative Commons Attribution 4.0 International License

\begin{abstract}
Résumé
Dans cet article, nous mettons en évidence trois façons dont les brevets sur les gènes pourraient nuire à la recherche scientifique. Premièrement, les lois relatives aux brevets sur les gènes risquent d'exacerber la culture du secret omniprésente en science. Deuxièmement, sans un accès à toutes les étiologies génétiques, les brevets sur les gènes peuvent limiter la capacité des chercheurs à étudier les maladies poly ou multigénétiques. Troisièmement, les brevets sur les gènes pourraient aboutir à un « maquis de brevets ».
\end{abstract}

\section{Mots clés}

brevets sur les gènes, recherche scientifique, culture du secret, maladies multigéniques, maquis de brevets

\begin{abstract}
Summary
In this paper, we point out three possible ways gene patents could impede scientific research. First, gene patent laws might exacerbate the culture of secrecy ubiquitous in science. Second, gene patents may limit researchers' ability to study poly or multigenic diseases without access to all genetic etiologies. Third, gene patents could result in a "patent thicket".
\end{abstract}

\section{Keywords}

gene patents, scientific research, culture of secrecy, multigenic diseases, patent thicket

Affiliations des auteurs / Author Affiliations

${ }^{1}$ Alden March Bioethics Institute, OBGYN Department, Albany Medical College, Albany, NY, USA

${ }^{2}$ Department of Radiology, Penn State University Hershey Medical Center, Hershey, PA, USA

\section{Correspondance / Correspondence}

Dr Lisa Campo-Engelstein, campoel@mail.amc.edu

\section{Conflit d'intérêts}

Aucune déclaré

\section{Conflicts of Interest \\ None to declare}

Gene patenting is a controversial topic, as seen with the recent Supreme Court case regarding Myriad Genetics' patent on the two BRCA genes associated with hereditary breast and ovarian cancer [1]. Much of the literature on this topic focuses on the deeper philosophical question of whether genes should be patentable since they exist in nature but can be isolated by human-made procedures $[2,3]$. Our focus in this paper is not on the normative aspects of gene patenting, but on the impact gene patenting has on current scientific research and how this may change if gene patent law is more stringently followed. We limit our discussion to two general types of gene patents: those that cover genetic sequences and related proteins and those that cover methods, such as diagnostic tests [4].

Patents are time-based monopolies on specific inventions, and they serve to prevent others from making, using, selling, or importing the invention [5]. Patents, in general, are intended to stimulate innovation by rewarding investors with the opportunity to temporarily dominate the market, produce a profit, and continue to invest in the future. Indeed, patents are supposed to encourage and engender more developments by enabling those with the patent to further invest in and dedicate themselves to their research. Many believe that gene patenting does not impede future research, mainly because most researchers do not check regularly for patents on research inputs, and instead proceed with their projects regardless of whether their work includes patented material $[6,7]$. Some argue that gene patents are unlikely to further impede research any more than some of the barriers that science already has in place, such as the need to protect one's work from criticism before enough evidence has been gathered or the intentional level of secrecy that allows one to be the first to publish their results [8]. 
Although gene patents do not currently adversely affect scientific research, how would scientific research be affected if gene patents were to be more strictly enforced? Some may claim this possible scenario is not worth contemplating, believing it is unlikely that the current status quo will change so drastically anytime in the near future. Yet, as we saw with the Myriad case, in which the Supreme Court ruled that "A naturally occurring DNA segment is a product of nature and not patent eligible merely because it has been isolated" [1], the landscape of gene patents is changing. Thanks to this case, the topic of gene patents has gained national prominence and increased scrutiny of this issue could lead to policy changes that further affect research. Further, scientists may gradually become advocates of the gene patenting laws as they gain experience with the gene patenting process and begin to hold more patents. Currently, 4,389 human genes have either been patented or had related intellectual property claims by more than 1,100 different claimants [9]. The DNA Patent Database, developed by the Kennedy Institute of Ethics at Georgetown University, routinely searches for DNA using class codes defined by United States Patent and Trademark Office and terms specific to nucleic acids, such as 'DNA', 'RNA', and 'nucleotide'. This database shows a steady increase in DNA patents, from 2,722 to 4,389 between 2005 and 2011 (https://dnapatents.georgetown.edu).

With this growing number of gene patents, there may be a greater interest in better enforcing the rights of patented property, primarily because the number of affected researchers will have grown. In addition, a recent study has shown that institutions are demonstrating an increasing awareness of the common disregard for current patents: $22 \%$ of respondents reported receiving notices from their institutions to respect patent rights compared to $15 \%$ five years ago [6]. Ignorance of existing patents is well known [7] and even documented by the National Health Service (NHS), which performs the majority of diagnostic testing in the United Kingdom. Just one successful case by a patent holder against an organization like the NHS can herald more stringent enforcement of patent law. For this reason, some argue that it is better to address these concerns proactively [10]. Yet, there may not be much concern for patent holders suing countries with publicly funded healthcare systems, such as Canada and many European countries, because the financial and political strength of their systems make them more difficult to go up against, which may explain why Myriad never sued these countries for patent rights on the BRCA mutations [11].

We fear that if gene patent law, as it is currently written, were to be upheld, there would be adverse effects on scientific research. Here, we briefly discuss three possible adverse effects.

First, gene patent laws might exacerbate the culture of secrecy ubiquitous in science. The drive to succeed in the scientific field inevitably hampers the willingness of researchers to share information with one another; it is well known that discovery and publication drives scientific research and boosts an academic's reputation. A better reputation increases grant money, tenure, and the likelihood of attracting quality students. All of these factors feedback on continuing to improve the academic's chances of success in the future [12]. Unfortunately, the process of attaining publication often - especially in the health sciences - requires secrecy in order to protect one's findings from becoming known to others, who may take that knowledge to secure a publication of their own. Research that is most likely to be published are those that reveal some result for the first time, and thus there is a great emphasis on being the first to publish on a specific topic.

However, this confidentiality can ultimately be counterproductive to the field of science. Studies have shown that collaboration among researchers is particularly important in providing access to experts in certain research areas as well as learning opportunities through colleagues who provide different perspectives [13]. Scientific collaboration has been categorized into four stages: Foundation, Formulation, Sustainment, and Conclusion [14]. Each stage consists of various factors that influence collaboration, and two important factors found in the first two stages in this system are relevant to gene patenting: Resource Accessibility and Intellectual Property and Other Legal Issues. Since gene patenting often requires researchers to pay and obtain a license in order to access data, this may form another barrier to the communication of research materials and tools between individuals 
working in a field that can best, and perhaps only, move forward with cooperation among research groups.

Second, while some diseases are known to be caused by one gene, such as Huntington's Disease, others are caused by several genes and environmental factors. To fully understand the many poly or multigenic diseases that fall into this latter category, such as Type 1 and Type 2 Diabetes [15], it is important for scientists to examine all genetic etiologies. If one or more contributing genes are patented, research on these diseases could be thwarted. Given the dramatic increase in gene patents, we can expect that more and more scientists will find themselves needing to use patented genes. Indeed, as the discovery of new disease states, pathologies, and treatments involving genes of interest begin to overlap, cooperation will play an increasingly important role, and anything that impedes cooperation, including gene patenting with significant enough penalties for infringement, may negatively affect the progress of research.

Third, it has been theorized that the continued patenting of genes will result in a "patent thicket", which refers to the difficulties associated with working on patented genes, including obtaining licenses and paying for those licenses. Many scientists may be discouraged by this additional work, and eventually there will likely be less work dedicated to improving techniques and processes that have already been patented [9]. The concern is that new projects will focus on genes for which there are no associated patents. Therefore, gene patenting could hinder research in the future, though it may not yet appear to be an issue. This is a serious consequence that should be considered very carefully in the controversy over gene patenting. Current literature argues that patents cannot impede research because in practice, no research institution has ever been sued for patent infringement [16]. However, there are two reasons for why there has yet to be litigation for patent infringement. First, the individual or research group may not have the financial resources to sue. Filing a lawsuit takes time, money, and resources. Second, those who realize that they have used patented material without authorization may simply backtrack, especially if they are at an early stage of their project and choose to work on another topic entirely. The lack of patent infringement, thus, cannot be reflective of the effect gene patenting could have on research.

Currently, there is no significant evidence that gene patents inhibit scientific research. However, this is not because gene patents do not have the potential to significantly impede scientific research; rather, it is because these patents are not being enforced. While it is possible that gene patent laws could continue to be ignored indefinitely, we doubt this will be the case given how rapidly the field of genetics is growing and the dramatic increase in the number of gene patents. It is thus pertinent to reflect on how gene patents could affect scientific research in the likely event that they start being enforced, as we have discussed in this paper.

\section{References}

1. United States Supreme Court Ruling. Association for Molecular Pathology v. Myriad Genetics, Inc. October 2012 Term.

2. Resnik DB. DNA patents and human dignity. Journal of Law, Medicine \& Ethics. 2001; (29)1:152-165.

3. Farrelly C. Gene patents and justice. Journal of Value Inquiry. 2007; (41)2-4:147-163

4. Boutros N. Race to the cure: Why gene patents pave the way for breast cancer research. American University Journal of Gender Social Policy and Law. 2011; 19(3):1009-1030.

5. Caulfield T, Gold ER, Cho MK. Patenting human genetic material: refocusing the debate. Nature Review Genetics. 2000; 1(3):227-231.

6. Walsh JP, Cho C, Cohen WM. Patents, material transfers and access to research inputs in biomedical research. Final Report to the National Academy of Sciences' Committee Intellectual Property Rights in Genomic and Protein-Related Inventions, 2005. 
7. Huys I, Matthijs G, Van Overwalle G. The fate and future of patents on human genes and genetic diagnostic methods. Nature Review Genetics. 2012; 13(6):441-8.

8. Resnik DB. DNA patents and scientific discovery and innovation: Assessing benefits and risks. Science and Engineering Ethics. 2001; 7(1):29-62.

9. Salzberg SL. The perils of gene patents. Nature Publishing Group. 2012; 91(6):969-71.

10. Hawkins N. The Impact of Human Gene Patents on Genetic Testing in the UK. Genetic Medicine. 2011; 13(4):320-324.

11. Williams-Jones B. History of a gene patent: tracing the development and application of commercial BRCA testing. Health Law Journal. 2002; 10:123-46.

12. Saladino TR. Seeing the Forest Through the Trees: Gene Patents and the Reality of the Commons. Berkeley Technical Law Journal. 2011; 26(1):301-328.

13. Hara N, Solomon P, Seung-Lye K, Sonnenwald DH. An emerging view of scientific collaboration: Scientists' perspectives on collaboration and factors that impact collaboration. Journal of the American Society for Information Science and Technology. 2003; 54(10):952965.

14. Sonnenwald D. Scientific Collaboration. Annual Review of Information Science and Technology. 2007; 41(1):643-681.

15. Bottino R, Trucco M. Multifaceted therapeutic Approaches for a multigenetic disease. Diabetes. 2005; 54 Supplement 2 S79-S86.

16. Holman CM. The Impact of Human Gene Patents on Innovation and Access: A Survey of Human Gene Patent Litigation. UC Berkeley Recent Work 2008. 